\title{
PENILAIAN TINGKAT KESEHATAN BANK SYARIAH DENGAN METODE CAMEL DAN REGC (STUDI PADA BANK BNI SYARIAH TAHUN 2011-2015)
}

\author{
Ahsan Putra Hafiz \\ Fakultas Ekonomi dan Bisnis Islam UIN STS Jambi \\ ahsanputra22@yahoo.com
}

\begin{abstract}
ABSTRAK
Metode penilaian kesehatan bank terus saja berkembang, ada dua metode yang dilakukan dalam penelitian ini, pertama metode CAMELS sesuai dengan peraturan BI No.6/10/PBI/2004. Dan yang kedua adalah metode RGEC yang merupakan pembaruan peraturan yang dilakukan oleh BI melalui Peraturan BI No. 13/1/PBI/2011 tentang Penilaian Tingkat Kesehatan Bank Umum yang berlaku sejak 1 Januari 2012. Penelitian ini bertujuan untuk membandingkan antara dua metode tersebut. Dan juga untuk mengetahui tingkat kesehatan Bank BNI Syari'ah dengan menggunakan metode CAMELS dan RGEC. Penelitian ini merupakan jenis penelitian deskriptif dengan pendekatan kuantitatif. Objek penelitian ini adalah laporan keuangan selama lima periode yaitu tahun 2011 sampai dengan 2015. Teknik pengumpulan data dalam penelitian ini adalah dengan cara menelaah catatan-catatan atau dokumen perusahaan. Analisis yang digunakan adalah metode CAMELS dan RGEC dengan menentukan tingkat kesehatan bank menjadi peringkat kesehatan bank. Hasil penelitian menunjukkan bahwa penilaian tingkat kesehatan Bank BNI Syari'ah dengan menggunakan metode CAMELS rata-rata menunjukkan predikat SANGAT SEHAT. Dan Bank BNI Syari'ah yang menggunakan metode RGEC ratarata menunjukkan predikat SEHAT. Sehingga kinerja Bank BNI Syari’ah harus dipertahankan dengan cara menjaga tingkat kesehatan bank.
\end{abstract}

Kata Kunci: Penilaian Tingkat Kesehatan Bank, CAMELS, RGEC.

\section{PENDAHULUAN}

Tingkat kesehatan bank merupakan aspek penting yang harus diketahui oleh stakeholders. Penilaian kesehatan bank akan berguna dalam menerapkan good 
corporate governance dan untuk menghadapi risiko di masa yang akan datang (PBI No.13/1/PBI/2011). Khususnya bagi para stakeholders adanya penilaian tingkat kesehatan bank akan memberi sinyal dalam pengambilan keputusan investasi. Semakin tinggi tingkat kesehatan bank maka akan berpengaruh pada harga saham bank tersebut dalam pasar saham. Penilaian tingkat kesehatan bank dilakukan dengan menganalisis laporan keuangan. Laporan keuangan adalah sarana yang menyediakan informasi keuangan sebagai bahan pertimbangan dalam pengambilan keputusan oleh pihak-pihak yang berkepentingan. ${ }^{1}$

Secara sederhana dapat dikatakan bahwa bank yang sehat adalah bank yang dapat menjalankan fungsi-fungsinya dengan baik, penilaian kesehatan bank sangat penting karena bank mengelola dana dari masyarakat yang dipercayakan kepada bank. Dengan kata lain, bank yang sehat adalah bank yang dapat menjaga dan memelihara kepercayaan masyarakat, dapat menjalankan fungsi intermediasi, dapat membantu kelancaran lalu lintas pembayaran serta dapat digunakan oleh pemerintah dalam melaksanakan berbagai kebijakannya, terutama kebijakan moneter. Bank Indonesia selaku bank sentral mempunyai peranan penting dalam mengatur perkembangan perbankan baik dengan sistem syariah ataupun konvensional. Merumuskan dan mengatur kebijakan-kebijakan yang terkini sesuai dengan kondisi ekonomi global, diharapkan perbankan (antara perbankan syari'ah dan konvensional) memiliki kinerja yang bagus sehingga dapat bersaing dalam memperebutkan pasar perbankan nasional di Indonesia dengan kriteria bank yang sehat. $^{2}$

Untuk itu Bank Indonesia menetapkan suatu ketentuan yang harus dipenuhi dan dilaksanakan oleh lembaga perbankan, yaitu berdasarkan surat keputusan direksi Bank Indonesia No. 30/12/KEP/DIR dan surat edaran Bank Indonesia No. 30/3/UPPB tanggal 30 April 1997 yaitu tentang Tata Cara Penilaian Tingkat Kesehatan Bank Indonesia. Pelaksanaan penilaian dilakukan dengan cara mengkualifikasikan beberapa komponen dari masing-masing faktor yaitu komponen Capital (Permodalan), Assets (Aktiva), Management (Manajemen), Earnings (Rentabilitas), Liquidity (Likuiditas) atau disingkat dengan istilah CAMEL. Dan ditambah lagi yaitu sensitivity of market (Senstivitas terhadap risiko pasar) atau

${ }^{1}$ I Dewa Ayu Esti Putri dan I Gst. Ayu Eka Damayanthi, Analisis Perbedaan TingkatKesehatan Bank BerdasarkanRGECPada Perusahaan Perbankan Besar Dan Kecil, E-Jurnal Akuntansi Universitas Udayana, Vol 5:2 (2013), hlm.485

${ }^{2}$ Ragil Setiabudi, Analisis Perbedaan Tingkat Kesehatan Bank Umum Syari'ah Berdasarkan Metode CAMELS dan RGEC peridode 2011-2013, skripsi, Universitas Islam Negeri Sunan Kalijaga Yogyakarta, hlm. 2 
disingkat dengan istilah CAMELS berdasarkan surat edaran Bank Indonesia nomor 6/23/DPNP tahun 2004. ${ }^{3}$

Krisis keuangan global yang terjadi beberapa tahun terakhir memberi pelajaran berharga bahwa inovasi dalam produk, jasa, dan aktivitas perbankan harus diimbangi dengan penerapan manajemen risiko yang memadai. Dengan begitu Bank Indonesia menyempurnakan metode penilaian tingkat kesehatan bank umum dari CAMELS menjadi RGEC sesuai dengan SE BI No. 13/24/DPNP tanggal 25 oktober 2011 tentang Penilaian Tingkat Kesehatan Bank Umum merupakan petunjuk pelaksanaan dari Peraturan Bank Indonesia No.13/1/PBI/2011 yang mewajibkan bank umum untuk melakukan penilaian sendiri (self assesment) tingkat kesehatan bank dengan menggunakan pendekatan risiko(Risk-based Bank Rating/RBRR) baik secara individual namun konsolidasi. ${ }^{4}$

Penilaian tingkat kesehatan bank dengan metode RGEC mencakup komponen-komponen Risk Profile (yang terdiri dari 8 jenis risiko yaitu risiko kredit, risiko pasar, risiko operasional, risiko likuiditas, risiko hukum, risiko stratejik, risiko kepatuhan dan risiko reputasi), Good Corporate Governance, Earnings (Rentabilitas)dan Capital (Permodalan) untuk menghasilkan peringkat komposit tingkat kesehatan bank. ${ }^{5}$ Untuk menilai suatu kesehatan bank dapat dilihat dari berbagai segi. Penilaian ini bertujuan untuk menentukan apakah bank tersebut dalam kondisi yang sehat, cukup sehat, kurang sehat atau tidak sehat sehingga Bank Indonesia sebagai pengawas dan pembina bank-bank dapat memberikan arahan atau petunjuk bagaimana bank tersebut harus dijalankan atau bahkan dihentikan kegiatan oprasinya. ${ }^{6}$

BNI Syariah adalah salah satu bank pemerintah, bank ini semula bernama Unit Usaha Syari'ah Bank Negara Indonesia yang merupakan anak perusahaan PT BNI Persero, Tbk, sejak 2010, Unit Usaha BNI Syariah berubah menjadi bank umum syariah dengan nama PT Bank BNI Syariah. BNI Syariah terus menunjukkan pertumbuhannya yang signifikan. Hal ini dapat dilihat dari laporan tahunan BNI Syariah yang terus meningkat.

${ }^{3}$ Melia Kusumawati, Analisis Komparatif Kinerja Keuangan Perbankan Berdasarkan Metode CAMELS Dan RGEC Pada Pt. Bank Mandiri (Persero) Tbk. Jurnal akuntansi, Universitas Negeri Surabaya, Vol 2:2.2014, hlm. 2

${ }^{4}$ Melia Kusumawati, Jurnal akuntansi, Universitas Negeri Surabaya, Vol 2:2.2014, hlm.3

2016

${ }^{5}$ Surat Edaran Bank Indonesia, Tentang Penilaian Tingkat Kesehatan Bank Umum, diakses 6 Oktober

${ }^{6}$ Kasmir, Bank dan Lembaga Keuangan Lainnya, edisi 1, cetakan ke-13, Jakarta: Rajawali Pers, September 2013, hlm. 44 
Tabel : Perkembangan LB, CAR \& NPF

\begin{tabular}{|l|l|l|l|}
\hline Tahun & \multicolumn{1}{|c|}{$\begin{array}{c}\text { Laba Bersih } \\
\text { (dlm jutaan } \\
\text { Rupiah) }\end{array}$} & CAR & NPF \\
\hline 2011 & 66.354 & $20,67 \%$ & $4,01 \%$ \\
\hline 2012 & 101.892 & $19,07 \%$ & $2,03 \%$ \\
\hline 2013 & 117.462 & $16,23 \%$ & $1,86 \%$ \\
\hline 2014 & 163.251 & $18,43 \%$ & $2,82 \%$ \\
\hline 2015 & 228.525 & $18,11 \%$ & $4,28 \%$ \\
\hline
\end{tabular}

Sumber: publikasi laporan keuangan BNI Syariah. ${ }^{7}$

Dilihat dari tabel perkembangan diatas bahwa laba bersih terus meningkat setiap tahunnya, akan tetapi CAR BNI Syariah menurun setiap tahunnya. Dan NPF BNI Syariah mengalami ketinggian pada pada tahun 2011dan menurun sedikit demi sedikit pada tahun 2012-2013, akan tetapi pada tahun 2014 dan 2015 mengalami kenaikan lagi, bahkan pada tahun 2015 lebih tinggi daripada tahuntahun sebelumnya. Dari sinilah penulis ingin meneliti bagaimana Bank BNI Syariah menilai, apakah sudah sehat, kurang sehat atau bahkan tidak sehat. Maka dari sinilah penulis ingin menjabarkan antara peraturan lama dengan peraturan yang baru dalam menilai tingkat kesehatan bank, sehingga penulis mengambil judul "Analisis Perbandingan Tingkat Kesehatan Bank Menggunakan Metode CAMELS dan RGEC Pada Bank BNI Syariah Periode 2011-2015”.

\section{HASIL PENILAIAN TINGKAT KESEHATAN BNI SYARI'AH}

\section{Penilaian CAMELS}

a. Capital (permodalan)

Komponen modal BNI Syari'ah terdiri dari modal inti dan modal pelengkap. Tahun 2011 BNI Syari'ah mempunyai modal sebesar 1.097.119.000,- kemudian meningkat pada tahun 2012 sebesar 1.365.396.000,dan mengalami penurunan pada tahun 2013 yaitu sebesar 1.198.081.000,kemudian mengalami kenaikan lagi pada tahun 2014 dan 2015 yaitu sebesar 2.004.358.000,- dan 2.254.181.000,-- Tabel dibawah menunjukkan peringkat nilai faktor permodalan BNI Syari'ah tahun 2011-2015. 
Tabel: penilaian peringkat faktor permodalan (CAR)

\begin{tabular}{|l|l|l|l|}
\hline Periode & CAR $(\%)$ & Peringkat & Keterangan \\
\hline Desember 2011 & 20,67 & 1 & Sangat sehat \\
\hline Desember 2012 & 19,07 & 1 & Sangat sehat \\
\hline Desember 2013 & 16,23 & 1 & Sangat sehat \\
\hline Desember 2014 & 18,43 & 1 & Sangat sehat \\
\hline Desember 2015 & 18,11 & 1 & Sangat sehat \\
\hline
\end{tabular}

Sumber: Data diolah

Dari tabel diatas menunjukkan bahwa perkembangan CAR BNI Syari'ah tahun 2011-2015 mengalami penurunan, akan tetapi tetap menempati pada peringkat satu atau predikat sehat.

b. Assets (kualitas aktiva)

Penilaian kualitas aktiva (NPA) dapat dilihat pada tabel dibawah ini:

Tabel: penilaian peringkat faktor kualitas aset (NPA)

\begin{tabular}{|l|l|l|l|}
\hline Periode & NPA $(\%)$ & Peringkat & Keterangan \\
\hline $\begin{array}{l}\text { Desember } \\
2011\end{array}$ & 2,72 & 1 & Sangat sehat \\
\hline $\begin{array}{l}\text { Desember } \\
2012\end{array}$ & 1,58 & 1 & Sangat sehat \\
\hline $\begin{array}{l}\text { Desember } \\
2013\end{array}$ & 1,53 & 1 & Sangat sehat \\
\hline $\begin{array}{l}\text { Desember } \\
2014\end{array}$ & 1,73 & 1 & Sangat sehat \\
\hline $\begin{array}{l}\text { Desember } \\
2015\end{array}$ & 2,50 & 1 & Sangat sehat \\
\hline
\end{tabular}

Sumber: data diolah

Dilihat dari tabel diatas diketahui bahwa NPA BNI Syaria'ah mengalami penurunan pada tahun 2011 sampai dengan 2014, dan mengalami kenaikan pada tahun 2015 namun tidak setinggi pada tahun 2011. Berdasarkan tabel diatas walaupun rasio NPA Bank BNI Syari'ah mengalami naik turun namun masih tetap menempat pada peringkat satu atau pada predikat sangat sehat. 
c. Earning (Rentabilitas)

Penilaian faktor rentabilitas adalah kemampuan bank dalam meningkatkan labanya apakah setiap periode atau untuk mengukur tingkat efisiensi usaha dan profitabilitas yang dicapai oleh BNI Syari'ah ${ }^{8}$. ROA BNI Syari'ah adalah seperti tabel dibawah ini:

1) $\operatorname{ROA}$ (Return On Assets)

Tabel: penilaian peringkat faktor Earning (ROA)

\begin{tabular}{|l|l|l|l|}
\hline Periode & ROA (\%) & Peringkat & Keterangan \\
\hline $\begin{array}{l}\text { Desember } \\
2011\end{array}$ & 1,05 & 2 & Sehat \\
\hline $\begin{array}{l}\text { Desember } \\
2012\end{array}$ & 1,29 & 2 & Sehat \\
\hline $\begin{array}{l}\text { Desember } \\
2013\end{array}$ & 1,22 & 3 & Cukup Sehat \\
\hline $\begin{array}{l}\text { Desember } \\
2014\end{array}$ & 1,13 & 3 & Cukup Sehat \\
\hline $\begin{array}{l}\text { Desember } \\
2015\end{array}$ & 1,34 & 2 & Sehat \\
\hline
\end{tabular}

Sumber: Data diolah

Dari tabel diatas dapat dilihat bahwa ROA Bank BNI Syari'ah pada tahun 2011 sampai dengan 2015 mengalami peningkatan dan penurunan, namun masih tetap berada pada peringkat ke dua yaitu pada predikat sehat.

2) BOPO (Beban Operasional Terhadap Pendapatan Operasional) Tabel: penilaian peringkat faktor Earning (BOPO)

\begin{tabular}{|l|l|l|l|}
\hline Periode & $\begin{array}{l}\text { BOPO } \\
(\%)\end{array}$ & Peringkat & Keterangan \\
\hline Desember 2011 & 90,89 & 2 & Sehat \\
\hline Desember 2012 & 88,79 & 1 & Sangat sehat \\
\hline Desember 2013 & 88,11 & 1 & Sangat sehat \\
\hline Desember 2014 & 89,80 & 2 & Sehat \\
\hline Desember 2015 & 89,63 & 2 & Sehat \\
\hline
\end{tabular}

Sumber: Data diolah

\footnotetext{
${ }^{8}$ Kasmir, Bank Dan Lembaga Keuangan Lainnya, Ed. Revisi, Cet ke-14, Jakarta Rajawali Pers, Juli
} 2014, hlm. 45 
Dari tabel diatas dapat dilihat bahwa BOPO BNI Syari'ah pada tahun 2011 hingga 2015 mengalami fluktuasi dalam melakukan kegiatan operasinya. Hal ini menunjukkan bahwa BOPO BNI Syari'ah masih berada pada peringkat satu dan dua atau pada predikat sehat dan sangat sehat.

3) Liquidity (Likuiditas)

Penilaian faktor likuiditas merupakan faktor untuk mengukur kemampuan bank dalam memenuhi kewajibannya jangka pendeknya pada saat ditagih? . FDR BNI Syari'ah adalah sebagai berikut:

Tabel : penilaian peringkat faktor Liquidity (FDR)

\begin{tabular}{|l|l|l|l|}
\hline Periode & FDR (\%) & Peringkat & Keterangan \\
\hline $\begin{array}{l}\text { Desember } \\
2011\end{array}$ & 78,64 & 2 & Sehat \\
\hline $\begin{array}{l}\text { Desember } \\
2012\end{array}$ & 85,29 & 3 & Cukup Sehat \\
\hline $\begin{array}{l}\text { Desember } \\
2013\end{array}$ & 98,42 & 3 & Cukup sehat \\
\hline $\begin{array}{l}\text { Desember } \\
2014\end{array}$ & 92,60 & 3 & Cukup sehat \\
\hline $\begin{array}{l}\text { Desember } \\
2015\end{array}$ & 91,94 & 3 & Cukup sehat \\
\hline
\end{tabular}

Sumber: Data diolah

Dari tabel diatas dapat dilihat bahwa FDR BNI Syaria'ah pada tahun 2011 sampai dengan 2013 mengalami kenaikan menunjukkan bahwa tingkat likuiditas bank rendah, dan sedikit menurun pada tahun 2014-2015, namun tetap saja FDR BNI Syari'ah menempati pada peringkat ke tiga atau dikatakan cukup sehat.

${ }^{9}$ Kasmir,Analisis Laporan Keuangan, hlm. 221 


\section{Penilaian RGEC}

a. Risk Profile (Profil Risiko)

1) Credit risk (Risiko Kredit)

Penilaian risiko kredit (NPF) dapat dilihat pada tabel dibawah ini:

Tabel: penilaian peringkat komponen profil risiko (NPF)

\begin{tabular}{|l|l|l|l|}
\hline Periode & NPF (\%) & Peringkat & Keterangan \\
\hline $\begin{array}{l}\text { Desember } \\
2011\end{array}$ & 4,01 & 3 & $\begin{array}{l}\text { Cukup } \\
\text { Memadai }\end{array}$ \\
\hline $\begin{array}{l}\text { Desember } \\
2012\end{array}$ & 2,03 & 2 & Memadai \\
\hline $\begin{array}{l}\text { Desember } \\
2013\end{array}$ & 1,86 & 1 & $\begin{array}{l}\text { Sangat } \\
\text { memadai }\end{array}$ \\
\hline $\begin{array}{l}\text { Desember } \\
2014\end{array}$ & 2,82 & 2 & Memadai \\
\hline $\begin{array}{l}\text { Desember } \\
2015\end{array}$ & 4,28 & 3 & $\begin{array}{l}\text { Cukup } \\
\text { Memadai }\end{array}$ \\
\hline
\end{tabular}

Sumber: Data diolah

Dari tabel diatas dapat dilihat bahwa NPF Bank BNI Syari'ah pada tahun 2011 sampai dengan 2015 mengalami naik dan turun artinya, kemungkinan bank mengalami banyak kerugian dan laba bank menurun. Akan tetapi NPF BNI Syari'ah masih bisa bertahan dan menempat pada predikat cukup memadai.

2) Liquidity Risk (Risiko Likuiditas)

Risiko ini merupakan perbandingan total asset likuid primer dan asset likuid sekunder dengan total asset.

Tabel: penilaian peringkat komponen profil risiko (Risiko Likuiditas)

\begin{tabular}{|l|l|l|l|}
\hline Periode & $\mathrm{RL}(\%)$ & Peringkat & Keterangan \\
\hline Desember 2011 & 25,7 & 1 & Sangat memadai \\
\hline Desember 2012 & 10,7 & 3 & Cukup memadai \\
\hline Desember 2013 & 6,50 & 3 & Cukup memadai \\
\hline Desember 2014 & 11,1 & 3 & Cukup memadai \\
\hline Desember 2015 & 12,17 & 3 & Cukup memadai \\
\hline
\end{tabular}

Sumber: Data diolah 
Dari tabel di atas dapat dilihat bahwa rasio likuiditas BNI Syari'ah tahun 2011-2013 mengalami penurunan dratis menunjukkan bahwa bank mengalami banyak kerugian dan juga kemungkinan laba bank akan menurun. Dan pada tahun 2014-2015 likuiditas bank mengalami sedikit kenaikan, menunjukkan bahwa bank akan bisa kembali menaikkan laba dan kerugian bank juga bisa diatasi. Dan dalam hal ini risiko likuiditas menempat pada peringkat ke tiga atau pada redikat cukup memadai.

b. Earnings (Rentabilitas)

Pada faktor rentabilitas rasio yang digunakan adalah rasio ROA yaitu membandingkan antara laba dengan total aktiva.

Tabel: penilaian peringkat komponen rentabilitas (ROA)

\begin{tabular}{|l|l|l|l|}
\hline Periode & ROA (\%) & Peringkat & Keterangan \\
\hline Desember 2011 & 1,05 & 1 & $\begin{array}{l}\text { Sangat } \\
\text { Memadai }\end{array}$ \\
\hline Desember 2012 & 1,29 & 1 & $\begin{array}{l}\text { Sangat } \\
\text { Memadai }\end{array}$ \\
\hline Desember 2013 & 1,22 & 1 & $\begin{array}{l}\text { Sangat } \\
\text { Memadai }\end{array}$ \\
\hline Desember 2014 & 1,13 & 1 & $\begin{array}{l}\text { Sangat } \\
\text { Memadai }\end{array}$ \\
\hline Desember 2015 & 1,34 & 1 & $\begin{array}{l}\text { Sangat } \\
\text { Memadai }\end{array}$ \\
\hline
\end{tabular}

Sumber: Data diolah

Dari tabel diatas rasio ROA BNI Syari'ah tahun 2011 sampai dengan 2015. menunjukkan bahwa keuntungan (laba) yang diperoleh BNI Syari'ah sangat stabil disetiap tahunnya. Dalam hal ini ROA BNI Syari'ah menempat pada peringkat satu atau dengan perdikat sangat memadai.

c. Capital (Faktor Permodalan)

Pada faktor permodalan rasio yang digunakan adalah rasio Capital Adequacy Ratio (CAR) adalah perbandingan jumlah modal dengan aktiva tertimbang menurut risiko (ATMR). 
Tabel: penilaian peringkat komponen permodalan (CAR)

\begin{tabular}{|l|l|l|l|}
\hline Periode & CAR (\%) & Peringkat & Keterangan \\
\hline Desember 2011 & - & - & - \\
\hline Desember 2012 & - & - & - \\
\hline Desember 2013 & - & - & - \\
\hline Desember 2014 & - & & \\
\hline Desember 2015 & 15,48 & 1 & $\begin{array}{l}\text { Sangat } \\
\text { memadai }\end{array}$ \\
\hline
\end{tabular}

Sumber: Data diolah

Dari tabel diatas dapat dilihat bahwa CAR BNI Syari'ah tahun 20112014 belum ada nilainya karna BNI Syari'ah belum menerapkan metode RGEC dan masih memakai metode CAMELS sebagai perhitungannya dan adanya hanya pada tahun 2015 saja. Dan dari rasio CAR yang ada di BNI Syariah tahun 2015 menunjukkan bahwa permodalan bank menempat pada peringkat kesatu atau dengan predikat sangat memadai.

\section{Perbandingan Tingkat Kesehatan BNI Syariah dengan Menggunakan Metode CAMELS dan RGEC Periode 2011-2015}

Setelah menghitung kinerja keuangan BNI Syari'ah dengan menggunakan metode CAMELS dan RGEC maka selanjutnya adalah membandingkan antara dua metode tersebut. Dari analisis kinerja keuangan BNI Syari'ah yang sudah di jabarkan diatas diketahui bahwa antara metode CAMELS dan RGEC mempunyai banyak kesamaan dalam penilaiannya, akan tetapi juga terdapat perbedaannya. Persamaan tersebut yaitu pada:

1. Faktor permodalan pada metode CAMELS dan RGEC secara penilaian sama, berbeda pada perhitungan ATMR nya, pada metode CAMELS ATMR dinilai berdasarkan risiko pasar dan risiko kredit, sedangkan ATMR pada metode RGEC dinilai berdasarkan risiko kredit, pasar dan operasional.

2. faktor kualitas asset, faktor likuiditas pada metode CAMELS yang memiliki penilaian yang sama dengan faktor profil risiko pada metode RGEC yaitu pada risiko kredit dan risiko likuiditas. Namun faktor profil risiko pada metode RGEC lebih menekankan pada penerapan menejemen risikonya.

3. Faktor rentabilitas (earning) pada metode CAMELS dan RGEC secara penilaian sama, perbedaannya terjadi pada analisis keuangannya. Pada metode CAMELS rasio yang digunakan adalah rasio ROA dan BOPO sedangkan pada metode RGEC rasio yang digunakan hanyalah rasio ROA saja. 
Faktor permodalan yang dihitung dengan rasio CAR pada metode CAMELS mengalami penurunan tiap tahunnya. Sedangkan pada metode RGEC rasio CAR BNI Syari'ah adanya pada tahun 2015 saja. Pada faktor kualitas asset pada metode CAMELS menunjukkan kinerja keuangan BNI Syari'ah berada pada rata-rata peringkat 1 atau dikatakan sangat baik. Nilai rasio NPA mengalami penurunan selama tahun 2011-2015, dan yang paling terlihat tinggi pada tahun 2011, walaupun asset bank menurun akan tetapi kualitas asset BNI Syari'ah masih dalam penilaian sangat baik. Faktor likuiditas pada metode CAMELS menunjukkan kinerja keuangan BNI Syari'ah cukup baik, hal ini dilihat dari nilai rasio likuiditas yang menggambarkan tingkat likuiditas BNI Syari'ah mengalami fluktuasi pada periode 2011-2015. Hal demikian juga ditunjukkan pada metode RGEC dalam menilai risiko kredit dan risiko likuiditas, dilihat dari nilai rasio NPF atas pembiayaan bermasalah mengalami penurunan dan tingkat likuiditas BNI Syari'ah mengalami fluktuasi pada periode 2011-2015. Sedangkan rasio ROA pada metode CAMELS dan RGEC menghasilkan nilai yang sama dikarenakan tidak ada perbedaan sistem penilaian antar keduanya, hanya beda pada rasio BOPO yang dimasukkan pada metode CAMELS saja dan tidak pada REGC. Tingkat rentabilitas pada BNI Syari'ah menggambarkan ketidak stabilan pada periode 2011-2015.

\section{PEMBAHASAN}

\section{Analisis CAMELS}

a. Capital (permodalan)

Capital Adequacy Ratio adalah perbandingan jumlah modal dengan aktiva tertimbang menurut risiko (ATMR), dalam CAMELS perhitungan Aktiva Tertimbang Menurut Resikonya meliputi risiko pasar dan risiko kredit saja, dengan perhitungan sebagai berikut:

$$
\begin{gathered}
\text { CAR }=\frac{\text { Total modal }}{\text { ATMR }} \times 100 \% \\
\text { Tahun } 2011 \\
\text { CAR }=\frac{1.045 .206+52.027}{5.286 .160+22.016}=\frac{1.097 .119}{5.308 .176} \times 100 \%=20,67 \% \\
\text { Tahun } 2012 \\
\text { CAR }=\frac{1.122 .982+75.036}{6.211 .331+72.477}=\frac{1.198 .018}{6.283 .808} \times 100 \%=19,07 \% \\
\text { Tahun } 2013 \\
\text { CAR }=\frac{1.262 .206+52.027}{8.255 .167+22.016}=\frac{1.365 .396}{8.413 .837} \times 100 \%=16,22 \%
\end{gathered}
$$


Tahun 2014

$$
\begin{aligned}
\mathrm{CAR} & =\frac{1.868 .375+135.983}{10.686 .023+192.597}=\frac{2.004 .358}{10.878 .620} \times 100 \%=18,43 \% \\
\text { Tahun } 2015 & \\
\mathrm{CAR} & =\frac{2.064 .262+189.919}{12.414 .816+32.478}=\frac{2.254 .181}{12.447 .294} \times 100 \%=18,11 \%
\end{aligned}
$$

b. Asset (kualitas aktiva)

Non Performing Asset (NPA) adalah rasio untuk menunjukkan kemampuan manajemen bank dalam mengelola aktiva produktif bermasalah terhadap total aktiva produktif, dengan perhitungan sebagai berikut:

$$
\begin{aligned}
& \text { NPA }=\frac{\text { Aktiva Produktif Bermasalah }}{\text { Aktiva Produktif }} \\
& \text { Tahun } 2011 \\
& \mathrm{NPA}=\frac{75.828+134.971+1.957}{7,826.113}=\frac{212.756}{7.826 .113}=2,72 \% \\
& \text { Tahun } 2012 \\
& \mathrm{NPA}=\frac{56.650+16.081+82.345}{9.769 .272}=\frac{155.076}{9.769 .272} \times 100 \%=1,59 \% \\
& \text { Tahun } 2013 \\
& \mathrm{NPA}=\frac{56.481+42.679+110.258}{13.647 .597}=\frac{20.948}{13,647.597} \times 100 \%=1,53 \% \\
& \text { Tahun } 2014 \\
& \mathrm{NPA}=\frac{99.814+78.463+246.397}{24.628 .547}=\frac{424.674}{24.628 .547} \times 100 \%=1,73 \% \\
& \text { Tahun } 2015 \\
& \mathrm{NPA}=\frac{219.167+118.991+423.624}{30.482 .144}=\frac{761.782}{30.482 .144} \times 100 \%=2,50 \%
\end{aligned}
$$

c. Earning (rentabilitas)

Pada komponen earning rasio yang digunakan adalah ROA dan BOPO. Rasio ROA adalah membandingkan antara laba dengan total aktiva, dengan perhitungan sebagai berikut:

$$
\begin{aligned}
\text { ROA } & =\frac{\text { Laba Sebelum Pajak }}{\text { Total Aktiva }} \times 100 \% \\
\text { Tahun } 2011 & \\
\text { ROA } & =\frac{89.256}{8.466 .887} \times 100 \%=1,1 \% \\
\text { Tahun } 2012 & \\
\text { ROA } & =\frac{137.744}{10.645 .313} \times 100 \%=1,3 \% \\
\text { Tahun } 2013 & \\
\text { ROA }= & \frac{179,616}{14.708 .504} \times 100 \%=1,22 \% \\
\text { ROA }= & \frac{\text { Tahun } 2014}{19.492 .133} \times 100 \%=1,13 \% \\
\text { Tahun } 2015 & =\frac{307.768}{23.017 .667} \times 100 \%=1,34 \%
\end{aligned}
$$


Rasio BOPO adalah membandingkan antara beban operasional terhadap pendapatan operasional, dengan perhitungan sebagai berikut:

$$
\begin{aligned}
& \mathrm{BOPO}=\frac{\text { Biaya Operasional }}{\text { Pendapatan Operasional }} \times 100 \% \\
& \text { Tahun } 2011 \\
& \mathrm{BOPO}=\frac{252.413+271.485+61+393.655}{1.009 .550}=\frac{917.614}{1.009 .550} \times 100 \%=90,89 \% \\
& \text { Tahun } 2012 \\
& \mathrm{BOPO}=\frac{293.054+151.305+673}{1.259 .539}=\frac{1.118 .312}{1.259 .539} \times 100 \%=88,79 \% \\
& \text { Tahun } 2013 \\
& \mathrm{BOPO}=\frac{418.332+118.065+884.109}{1.612 .222}=\frac{1.420 .506}{1.612 .222} \times 100 \%=88,11 \% \\
& \text { Tahun } 2014 \\
& \mathrm{BOPO}=\frac{691.445+1.264 .055}{2.033+110+144.294}=\frac{1.955 .500}{2.177 .404} \times 100 \%=89,80 \% \\
& \text { Tahun } 2015 \\
& \mathrm{BOPO}=\frac{846.069+1.460 .278}{2.435 .360+137.828}=\frac{2,306.347}{2.573 .188} \times 100 \%=89,63 \%
\end{aligned}
$$

d. Liquidity (likuiditas)

Pada komponen ini rasio yang digunakan adalah rasio Financing To Deposit Ratio (FDR), yaitu membandingkan antara kredit dengan dana masyarakat, dengan perhitungan sebagai berikut:

$$
\begin{aligned}
& \mathbf{F D R}=\frac{\text { Jumlah kredit yang diberikan }}{\text { Dana yang diterima }} \times 100 \% \\
& \text { Tahun } 2011 \\
& \mathrm{FDR}=\frac{5.310 .292}{6.752 .263} \times 100 \%=78,64 \% \\
& \text { Tahun } 2012 \\
& \mathrm{FDR}=\frac{7.631 .994}{8.947 .729} \times 100 \%=85,29 \% \\
& \text { Tahun } 2013 \\
& \mathrm{FDR}=\frac{11.242 .241}{11,422.190} \times 100 \%=98,42 \% \\
& \text { Tahun } 2014 \\
& \mathrm{FDR}=\frac{15.044 .158}{16.246 .405} \times 100 \%=92,60 \% \\
& \text { Tahun } 2015 \\
& \mathrm{FDR}=\frac{17.765 .097}{19_{3} 322.756} \times 100 \%=91,94 \%
\end{aligned}
$$




\section{Analisis RGEC}

a. Risk profile (profil risiko)

1) Credit risk (risiko kredit)

Untuk menghitung risiko kredit maka dengan membandingkan kredit macet dengan jumlah kredit yang disalurkan ${ }^{10}$. Dengan perhitungan sebagai berikut:

$$
\begin{aligned}
& \mathrm{NPF}=\frac{\text { Pembiayaan bermasalah }}{\text { Total pembiayaan }} \times 100 \% \\
& \text { Tahun } 2011 \\
& \mathrm{NPF}=\frac{75.828+134.971+1.957}{5.310 .292}=\frac{212.756}{5.310 .292} \times 100 \%=4,01 \% \\
& \text { Tahun } 2012 \\
& \mathrm{NPF}=\frac{56.650+16.081+82.345}{7.631 .994}=\frac{15.5 .076}{7.631 .994} \times 100 \%=2,03 \% \\
& \text { Tahun } 2013 \\
& \mathrm{NPF}=\frac{56.481+42.679+110.258}{11.242 .241}=\frac{209.481}{11.242 .241} \times 100 \%=1,86 \% \\
& \text { Tahun } 2014 \\
& \mathrm{NPF}=\frac{99.814+78.463+246.397}{15.044 .158}=\frac{424.674}{17.388 .598} \times 100 \%=2,82 \% \\
& \text { Tahun } 2015 \\
& \mathrm{NPF}=\frac{219,167+118.991+423.624}{17.765 .097}=\frac{761.782}{17.765 .097} \times 100 \%=4,28 \%
\end{aligned}
$$

2) Liquidity risk (risiko likuiditas)

Risiko ini merupakan perbandingan total asset likuid primer dan asset likuid sekunder dengan total asset, dengan perhitungan sebagai berikut:

$$
\begin{aligned}
& L R=\frac{\text { aset likuid primer }- \text { aset likuid sekunder }}{\text { Total aset }} \times 100 \% \\
& \text { Tahun } 2011 \\
& \mathrm{LR}=\frac{(70.235+2.297 .693]-192.801}{8.466 .887}=\frac{2.175 .127}{8.466 .887} \times 100 \%=25,7 \% \\
& \text { Tahun } 2012 \\
& \mathrm{LR}=\frac{(144.906+1.039 .298)-46.861}{10.645 .313}=\frac{1.137 .343}{10.645 .313} \times 100 \%=10,7 \% \\
& \text { Tahun } 2013 \\
& \mathrm{LR}=\frac{(201.157+774.558)-19.408}{\mathbf{1 4 . 7 0 8 . 5 0 4}}=\frac{956.307}{14.708 .504} \times 100 \%=6,51 \% \\
& \text { Tahun } 2014 \\
& \mathrm{LR}=\frac{(153.331+2.008 .512)-15.654}{19.442 .112}=\frac{2.146 .189}{19.442 .112} \times 100 \%=11,04 \% \\
& \text { Tahun } 2015 \\
& \mathrm{LR}=\frac{(145.965+2.673 .479)-18.942}{23.017 .667}=\frac{2.800 .502}{23.017 .667} \times 100 \%=12,17 \%
\end{aligned}
$$

\footnotetext{
${ }^{10}$ Kasmir, Analisis Laporan Keuangan, Ed 1, Cet ke-7, Jakarta Rajawali Pers, Januari 2014, hlm. 228
} 
b. Earning (rentabilitas)

Pada faktor rentabilitas rasio yang digunakan adalah rasio ROA yaitu membandingkan antara laba dengan total aktiva, dengan perhitungan sebagai berikut:

$$
\begin{aligned}
& \text { ROA }=\frac{\text { Laba Sebelum Pajak }}{\text { Total Aktiva }} \times 100 \% \\
& \text { Tahun } 2011 \\
& \mathrm{ROA}=\frac{89.256}{8.466 .887} \times 100 \%=1,1 \% \\
& \text { Tahun } 2012 \\
& \mathrm{ROA}=\frac{137.744}{10.645 .313} \times 100 \%=1,3 \% \\
& \text { Tahun } 2013 \\
& \mathrm{ROA}=\frac{179.616}{14.708 .504} \times 100 \%=1,22 \% \\
& \text { Tahun } 2014 \\
& \mathrm{ROA}=\frac{220.133}{19.492 .112} \times 100 \%=1,13 \% \\
& \text { Tahun } 2015 \\
& \mathrm{ROA}=\frac{307.768}{23.017 .667} \times 100 \%=1,34 \%
\end{aligned}
$$

c. Capital (permodalan)

Pada faktor permodalan pada metode RGEC perhitungan ATMR nya meliputi risiko kredit, pasar dan operasional, akan tetapi pada faktor ini ATMR untuk risiko operasional tidak ada pada tahun 2011-2014 dan yang ada hanya pada tahun 2015 saja. Dengan perhitungan sebagai berikut:

$$
\begin{gathered}
\text { CAR }=\frac{\text { Total modal }}{\text { ATMR }} \times 100 \% \\
\text { Tahun } 2015 \\
\text { CAR }=\frac{2.064 .262+189.919}{12.414 .816+32.478+2.111 .736}=\frac{2.254 .181}{14.559 .030} \times 100 \%=15,48 \%
\end{gathered}
$$

\section{PENUTUP}

Berdasarkan hasil analisis kinerja keuangan pada Bank BNI Syariah periode 20112015 dapat ditarik kesimpulan sebagai berikut:

1. Penilaian tingkat kesehatan BNI Syari'ah dengan menggunakan metode CAMELS menunjukkan predikat kesehatan bank tersebut sudah sesuai dengan standar yang telah ditetapkan oleh BI. Untuk periode 2011 rata-rata berada padaperingkat dua yaitu sehat, untuk periode 2012 dan 2013 rata-rata berada pada peringkat satu yaitu sangat sehat, dan pada periode 2014 dan 2015 rata-rata berada pada peringkat dua yaitu dikatakan sehat. 
2. Penilaian tingkat kesehatan BNI Syari'ah periode 2011-2015 dengan menggunakan metode RGEC menunjukkan predikat kesehatan tersebut sudah sesuai dengan standar yang telah ditetapkan oleh BI. Untuk faktor profil risiko yaitu risiko kredit disimpulkan dengan peringkat satu yang mencerminkan kondisi bank secara umum dalam keadaan sangat sehat, dan risiko likuiditas disimpulkan dengan peringkat ketiga yang mencerminkan kondisi bank secara umum cukup sehat. Untuk faktor rentabilitas disimpulkan dengan peringkat dua yang mencerminkan kondisi bank secara umum dalam keadaan sehat, dan untuk faktor permodalan disimpulkan dengan peringkat satu yang mencerminkan kondisi bank dalam keadaan sangat sehat.

3. Metode CAMELS dan RGEC adalah dua diantara beberapa peraturan Bank Indonesia yang digunakan untuk menganalisis tingkat kesehatan bank. Metode CAMELS menilai tingkat kesehatan bank dari faktor permodalan, kualitas aset, manajemen, rentabilitas, likuiditas, dan sensitivitas pasar. Metode RGEC menilai tingkat kesehatan dari faktor risiko profil, GoodCorporate Governance, rentabilitas, dan permodalan.

Terdapat perbedaan analisis antara dua metode tersebut, jika menggunakan metode CAMELS laporan keuangan BNI Syariah dikategorikan Sangat Sehat tetapi jika menggunakan metode RGEC laporan keuangan BNI Syariah dikategorikan Sehat. Hal tersebut terjadi karena metode CAMELS sebenarnya telah memberikan gambaran tingkat kesehatan bank yang efektif akan tetapi metode CAMELS tidak memberikan suatu kesimpulan yang mengarahkan ke suatu penilaian. Antar faktor memberikan penilaian yang sifatnya bisa berbeda, sedangkan metode RGEC lebih menekankan akan pentingnya kualitas manajemen. Manajemen yang berkualitas tentunya akan mengangkat faktor pendapatan dan juga faktor permodalan secara langsung maupun tidak langsung. 


\section{DAFTAR PUSTAKA}

Angrawit Kusumawardani, Analisis Perbandingan Tingkat Kesehatan Bank DenganMenggunakan Metode CAMELS dan RGEC Pada Pt. Bank XXX Periode 2008-2011, Jurnal Ekonomi Bisnis, Volume 19 No. 3, Desember 2014.

Bayu Aji Permana, Analisis Tingkat Kesehatan Bank Berdasarkan MetodeCAMELS dan Metode RGEC, Jurnal Akuntansi, Vol 1:1. Universitas Negeri Surabaya.

Herman Darmawi, Manajemen Perbankan, Jakarta: PT Bumi Aksara, Cet Ke-2, 2012.

Ismail, Manajemen Perbankan: Dari Teori menuju Aplikasi, Jakarta: Kencana, 2011.

Kasmir, Bank dan Lembaga Keuangan Lainnya, edisi 1, cetakan ke-13, Jakarta: Rajawali Pers, September 2013.

Kasmir, Manajemen Perbankan, Jakarta:PT Raja Grafindo Persada, 2006.

Kasmir, Analisis Laporan Keuangan, edisi 1, cetakan ke-7, Jakarta: Rajawali Pers, Januari 2014.

Manajemen Risiko 1, Modul Sertifikasi Manajemen Risiko Tingkat 1, Ikatan Bankir Indonesia.

Sugiyono, Metode Penelitian Kuantitatif Kualitatif dan R\&D, CV. Alfabeta, cet ke-7 April 2009.

Hambali Kassah, Analisis Kinerja Kenangan Bank Umum Syariah Menggunakan Metode CAMEL dan RGEC Periode 2012-2014, skripsi, Universitas Islam Negeri Sunan Kalijaga Yogyakarta.

I Dewa Ayu Esti Putri dan I Gst. Ayu Eka Damayanthi, Analisis Perbedaan TingkatKesehatan Bank BerdasarkanRGECPada Perusahaan Perbankan Besar Dan Kecil, E-Jurnal Akuntansi Universitas Udayana, Vol 5:2 (2013).

Melia Kusumawati, Analisis Komparatif Kinerja Kenangan PerbankanBerdasarkan Metode CAMELS Dan RGEC Pada Pt. BankMandiri (Persero) Tbk. Jurnal akuntansi,Universitas Negeri Surabaya, Vol 2:2.2014.

Ragil Setiabudi, Analisis Perbedaan Tingkat Kesehatan Bank Umum Syari'ah Berdasarkan Metode CAMELS dan RGEC peridode 2011-2013, skripsi, Universitas Islam Negeri Sunan Kalijaga Yogyakarta. 
Santi Budi Utami, Perbandingan Analisis CAMELS dan RGEC Dalam Menilai Tingkat Kesehatan Bank (Studi Pada Pt Bank. Negara Indonesia, Tbk Tabun 2012-2013), skripsi, Fakultas Ekonomi Universitas Negeri Yogyakarta.

Surat Edaran BI No. 6/23/DPNP, Jakarta 31 Mei 2004 tentang Sistem Penilaian Tingkat Kesehatan Bank Umum.

Surat Edaran BI No. 13/24/DPNP, Jakarta 25 Oktober 2011 tentang Penilaian Tingkat Kesehatan Bank Umum. 